\title{
IMPLEMENTATION OF SUSTAINABLE MOBILITY IN EDUCATION
}

\section{Tatjana Resnik Planinc, Matej Ogrin, Mojca Ilc Klun, Kristina Glojek: Imple- mentation of Sustainable Mobility in Education. Zbirka GeograFF 23. Znan- stvena založba Filozofske fakultete Univerze v Ljubljani in Oddelek za geografijo, I37 str. Ljubljana, 20 I7.}

Koncept trajnostne mobilnosti, ki je v zadnjem obdobju pomembno pridobil na pomenu, je eden od odgovorov na težave, ki jih povzroča zadovoljevanje naraščajočih potreb po mobilnosti: tako z vidika stroškov gradnje novih prometnic in krepitve obstoječih kot tudi z vidika okoljskih posledic naraščajočega prometa.

Trajnostna mobilnost zahteva korenito spremembo formalnih in neformalnih institucij, zato je pot do ustreznega udejanjanja zelo dolga, odvisna pa je od stopnje gospodarske razvitosti, družbenega razvoja, političnega sistema posamezne države in ozaveščenosti ter izobraženosti njenih prebivalcev. Le ti bodo s svojimi zahtevami in aktivnim državljanstvom uspeli premakniti ukoreninjene vzorce mobilnosti. Ta vidik implementacije trajnostne mobilnosti naslavlja znanstvena monografija $\mathrm{z}$ naslovom Implementation of Sustainable Mobility in Education.

V letu 2017 izdana znanstvena monografija je 23. knjiga v zbirki GeograFF, ki jo izdaja Oddelek za geografijo Filozofske fakultete Univerze v Ljubljani. Njeni avtorji so Tatjana Resnik Planinc, Matej Ogrin, Mojca Ilc Klun in Kristina Glojek. Monografijo je uredila Katja Vintar Mally. GeograFF 23 obravnava različne vidike trajnostne mobilnosti na 137 straneh, opremljen pa je s 36 slikami ter 2 preglednicama. Uporaba angleškega jezika spodbuja mednarodni domet monografije.

Monografijo sestavlja 9 poglavij v dveh vsebinskih sklopih. Prvi del monografije je namreč bolj naravnan k celoviti obravnavi mobilnosti, medtem ko se proces izobraževanja vključi v drugem delu knjige.

Po uvodnih mislih (1. poglavje) so v prvem vsebinskem sklopu obravnavani osnovni pojmi s področja prometa in trajnostne mobilnosti (2. poglavje). Analizirani so izbrani geografski učinki prometa, predvsem na rabo in fragmentacijo prostora (promet je njegov velik porabnik), emisije toplogrednih plinov in onesnaževanje zraka (promet je postal pomemben dejavnik onesnaževanja ozračja) ter vpliv (odpadnih snovi iz prometa) na kakovost površinskih vod in podtalnice. V nadaljevanju poglavja so podrobneje prikazani številni pozitivni učinki trajnostne mobilnosti: obrnjena hierarhija oblik 
prometa, zmanjšanje energetske odvisnosti od fosilnih goriv, zadovoljevanje potreb po mobilnosti za vse socialne skupine, spreminjanje rabe cest, vračanje k osnovnim funkcijam mest, vpeljevanje novih tehnologij ter spremembe v prostorskem in prometnem planiranju in ogrodju politik, ki spodbujajo trajnostno mobilnost. V 3. poglavju so obravnavani normativni viri, ki spodbujajo trajnostno mobilnost v Sloveniji. Avtorji opozarjajo na neustrezen hierarhični pristop k njihovemu oblikovanju in časovno zaostajanje pri njihovem sprejemanju.

Drugi vsebinski sklop se nanaša na vrednotenje in načrtovanje trajnostne mobilnosti v procesu izobraževanja. Po analizi šolskih kurikulov na predšolski, osnovnošolski in srednješolski ravni (4. poglavje) sledijo rezultati raziskave o odnosu učiteljev do trajnostne mobilnosti (5. poglavje). Obsežen del monografije obravnava trajnostno mobilnost med mladimi (6. poglavje). Prikazani so rezultati različnih projektov ter izkušnje s promocijo trajnostne mobilnosti med mladimi. Sklop zaokroži analiza percepcije trajnostne mobilnosti med študenti geografije na Oddelku za geografijo Filozofske fakultete Univerze v Ljubljani (7. poglavje).

V zadnjem delu monografije (8. poglavje) so podrobneje predstavljeni trije primeri ukrepov, ki so spodbudili trajnostno mobilnost: uvajanje kolesarjenja oziroma kolesarskih iger v osnovne šole na Danskem, oživitev lokalne proge na Južnem Tirolskem (Merano-Malles) ter ukrep subvencioniranja cene vozovnic za dijake in študente v Sloveniji, ki je pomembno spodbudil večjo uporabo javnega prometa med dijaki in študenti. Vsi obravnavani ukrepi dokazujejo, da je z ustreznimi finančnimi in organizacijskimi ukrepi mogoče $v$ relativno kratkem času pomembneje spremeniti trend v smer večje uporabe javnega prometa.

Monografijo zaokrožijo sklepne misli (9. poglavje) s povzetkom temeljnih dognanj.

Avtorji monografije opisujejo različne možnosti za trajnostno mobilnost ter spodbujajo k razmišljanju, kako lahko vsak posameznik na podlagi zbranih primerov prispeva $\mathrm{k}$ doseganju razvojnih ciljev na področju trajnostne mobilnosti. Kljub prikazanim primerom dobre prakse in številnim pozitivnim izkušnjam, ki so prepričali vsaj del mladih v uporabo trajnostnih oblik prometa, pa je potrebno prizadevanja za trajnostno mobilnost podkrepiti s celostnimi pristopi, ki pa zahtevajo aktivno vlogo različnih deležnikov. Poleg zgleda staršev je izjemno pomembna tudi ustrezna obravnava trajnostne mobilnosti v šolskih kurikulih v celotni izobraževalni vertikali: od vrtca do univerze. GeograFF 23 je pri tem lahko v veliko pomoč.

Simon Kušar 